NBER WORKING PAPER SERIES

\title{
REGULATION, DISTRIBUTION EFFICIENCY, AND RETAIL DENSITY
}

\author{
David Flath \\ Working Paper 9450 \\ http://www.nber.org/papers/w9450 \\ NATIONAL BUREAU OF ECONOMIC RESEARCH \\ 1050 Massachusetts Avenue \\ Cambridge, MA 02138 \\ January 2003
}

This paper was prepared for the volume on Structural Impediments to Growth that is being edited by Magnus Blomstrom, Jennifer Corbett, Fumio Hayashi and Anil Kashyap for the NBER and will be published by the University of Chicago Press. This research was supported by a grant from the Abe Fellowship Program of the Social Science Research Council and the American Council of Learned Societies with funds provided by the Japan Foundation Center for Global Partnership. I also thank Tatsuhiko Nariu for many useful discussions, Anil Kashyap for his very helpful suggestions, and Gary Saxonhouse and others for their comments on the paper at the March 2002 conference in Tokyo sponsored by NBER. The views expressed herein are those of the authors and not necessarily those of the National Bureau of Economic Research.

C2003 by David Flath. All rights reserved. Short sections of text not to exceed two paragraphs, may be quoted without explicit permission provided that full credit including notice, is given to the source. 
Regulation, Distribution Efficiency, and Retail Density

David Flath

NBER Working Paper No. 9450

January 2003

JEL No. I50, I81, P52

\section{$\underline{\text { ABSTRACT }}$}

After outlining characteristics of Japan's distribution sector, a comprehensive international comparison of it to those of other nations is presented and analyzed for underlying differences. This leads to an explanation of Japan's retail store density, which is then related to the structure of wholesale channels. Next, some details on the Large Store Law of Japan and regulatory distortion, including empirical evidence on its extent are offered. Data on the structure of the retail sector by store format and on differences among prefectures in density and format are then presented.

David Flath

Department of Economics

North Carolina State University

Raleigh, NC 27695-8110

david_flath@ncsu.edu 
Japan's distribution sector employs about one-sixth of the nation's labor force and accounts for around one-eighth of GDP, large enough to matter for any economy-wide assessment of barriers to growth and efficiency. Moreover, the phrase "inefficient distribution" has been repeated so many times in reference to Japan that one might suppose the evidence of gross distortion is overwhelming. It is not.

Certainly regulatory limits on large stores have had an effect on the numbers of stores of differing formats, but the undeniable peculiarities of Japan' $s$ distribution sector can be explained by fundamentals: car ownership, size of dwelling, and geography. Accounting for such fundamentals explains much of the variation in retail density between Japan and other countries, as well as across prefectures within Japan. Moreover, changes in these factors can be related to changes in the structure of retailing. ${ }^{1}$

This paper does three things. First, it compiles facts on the state of Japan's distribution system and puts them in historical and international context. This includes an explanation of retail store density and its relation to wholesale channels. Second, the chapter describes the logical framework behind the still widely held view that regulation, in particular the Large Store Law (repealed in 2000), is the key determinant of the structure of Japan's distribution system, and derives some testable predictions about what this implies. Third, it provides new evidence on whether the testable predictions are true. This includes looking at differences among prefectures and over time in retail density and format.

\section{Characteristics of Japan's Distribution Sector}

The peculiarities of Japan' s distribution sector include the myriad of small stores and lack of large stores, multiple wholesale steps, and ubiquity of vertical restraints. Some relevant data are in Table 1.

In the late 1990s Japan had 11 stores per thousand inhabitants, almost twice the US, and four times the UK, levels. The typical US supermarket in 2000 was almost five times the size of a Japanese equivalent, which was not quite the size of two basketball courts. Many stores in Japan are family enterprises with even smaller floor space. The average number of workers per store in Japan is half the US figure.

Fragmentation of the retail sector in Japan is accompanied by long and complex wholesale marketing channels. This is evident in several statistics. Japan's distribution sector employment is disproportionately concentrated in wholesaling compared to the United States, and the fraction of wholesalers' revenue from sales to other wholesalers is much higher in Japan.

Finally, the ubiquity of manufacturer-imposed pricing rules, customer assignments, and stipulations of exclusivity can be judged from the large fraction of wholesalers reporting participation in manufacturer-initiated "distribution keiretsu" : 45\% in 1992, although this is down from 70\% in 1986 (Chusho-kigyo-cho 1994, p 180 table 9). No direct comparison with the United States can be made, but such practices frequently run afoul of US antitrust laws and thus undoubtedly are less widespread.

\footnotetext{
${ }^{1}$ Other investigators who argue that factors besides regulation are important in discussions of Japan's distribution system include Nariu (1994), Maruyama et al (1991), and Miwa and Ramseyer (2002). For an overview of my work and that of some other scholars, see Flath (2000, ch 14).
} 


\section{International Perspective}

This section presents a comprehensive comparison of Japan's distribution sector with those of other nations. Table 2 depicts statistics for OECD countries on density of retail stores, employment per store, and value-added and employment in wholesaling and retailing.

The countries are listed in ascending order of stores per thousand inhabitants in the mid 1990s. Japan is in the bottom third of the list, having moved up since 1982 when it had 14.3 stores per thousand.

A simple index of the average productivity of labor employed in the distribution sector relative to the average productivity of labor in the overall economy can be obtained by dividing the share of distribution sector value-added in GDP by the share of distribution sector employment in the total labor force. Countries with higher standards of living (relatively high GNP per person in PPP units) tend to have wider discrepancies in average labor productivity between distribution and other sectors. (The United States is a regression outlier, but Japan is not). This has a simple interpretation: it reflects the generally slower pace of technical change in services compared to manufacturing, something first noted by William Baumol. ${ }^{2}$

Japan' s index stands at 0.69 , which is below the 0.75 average for all the countries. This is expected, given high standard of living. (The United States does not fit the pattern; its index of 0.92 is above the international average. ) The upshot is that the variation in the index across countries probably is more reflective of international differences in average productivity of manufacturing than of distribution.

Countries with lower standards of living tend to have more stores per person, and smaller average store size (measured as average employment per store). The association many have made between Japan's ubiquity of small stores and economic backwardness is based on this pattern.

\section{Explaining Retail Store Density}

There are two broad types of economic model for explaining the overall density of retail stores, those that presume the density of stores attains the economic optimum but without explicitly modeling how prices are set, and those that presume the density of stores is the maximum consistent with positive profits given some explicit model of pricing by firms. Flath (1990) and Matsui and Nariu (2001) adopt the social optimality approach. Heal (1980) and Gabszewicz and Thisse (1986) model pricing explicitly and presume free entry.

The comparative statics of store density are qualitatively the same for both types of model. A proliferation of stores shifts some costs of storing and transporting goods from households to the distribution sector.

\footnotetext{
2 A simple OLS regression of the natural logarithm of the labor productivity index (for 1996-97) on the natural logarithm of GNP per person measured in purchasing power units (for 1998) is: $\ln ($ Index $)=4.1-0.45 \mathrm{ln}$ (GNP per person in PPP units) $(\mathrm{t}-\mathrm{stat}=-3.8) ;$ number of observations $=20 ; \mathrm{R} 2=0.44$.
} 
Thus, it is appropriate to base empirical analysis of international variation in retail density on factors associated with the costs of transporting and storing goods of both households and firms. This is exactly the approach taken by Flath and Nariu (1996) using data from the early 1980s. Here that exercise is repeated with more recent data.

Table 3 presents data on some variables associated with the costs and benefits of a proliferation of stores for various OECD nations, mostly from around 1996. The variables are proxies for things that affect the relative efficiency of households and firms at storing and transporting goods.

Crowded living space (CRWDNG) increases willingness to pay a premium to shop nearby. Car ownership (CARS) lowers household costs of shopping, and thus lowers the premium. The more urbanized an economy (URBAN), then, for any given expansion in the number of stores per person, the smaller the effect on the average distance between stores and residences, and so, the smaller marginal benefit from proximity. If a nation is geographically compact (LENGTH) like Japan, rather than dispersed over half a continent like the United States, the added costs of restocking a multiplicity of stores is reduced. A proliferation of trucks (TRUCKS), and the infrastructure of roads that make it worthwhile to use trucks, lowers the added costs of restocking a multiplicity of stores as opposed to a smaller number of larger ones.

Table 4 shows that all of these contribute to the cross-country variation in number of stores per person in the expected way. The estimates in the first two columns include as an explanatory variable the average number of persons per room, a proxy for the dearness of household storage space. This variable is available only for some of the countries. Excluding it, and thus enlarging the sample, narrows the standard errors of estimates of the other coefficients. This possibly reinforces confidence that the results are qualitatively valid.

Japan is not a regression outlier. Stores per thousand persons predicted by regressions excluding Japan are 11.8 with crowding and 11.7 without, statistically indistinguishable from the actual value of 11.3. These results very much resemble those obtained in Flath and Nariu (1996) for a slightly different set of countries using data from around 1980.

The conclusion remains that Japan' s relatively high density of retail stores is due to its paucity of private cars, confined household living space, geographic centricity, and super-abundance of trucks.

All of this pointedly leaves regulation out of the picture. Partly this reflects the lack of a suitable proxy for regulation that can be included in the regression equation. But it also reflects a judgement that regulation is a corollary of economic variables like the ones already in the equation. I return to this point later.

\section{Wholesale Channels}

The focus so far has been on the density of stores. A related issue is the extent to which Japan's complex wholesale marketing channels are induced by its high retail store density, as opposed to reflecting some idiosyncrasy.

Proliferation of stores induces branching of logistical arteries to economize

on transport costs. Such branching does not by itself imply a multiplicity of wholesale steps, but would seem to lower the costs of a profusion of wholesalers. 
Evidence suggests Japan' s high retail density and wholesale complexity are intertwined. Nariu and Flath (1993) construct estimates of the average number of steps in matched wholesale industries of Japan and the United States for the early 1980s. Besides confirming that Japanese wholesale channels have on average more steps (1.8) than US ones (1.4), we also showed that the variation in number of steps across wholesale marketing channels is highly correlated between Japan and the United States, and for consumer products is also related to the relative density of stores. ${ }^{3}$

In other words, there are common influences operating on the length of wholesale channels in both countries. Also, the number of wholesale steps in Japan is greater for products (such as food) that have particularly many retail stores compared to the United States. This suggests that Japan's elephantine wholesale sector is to some extent due to its proliferation of stores.

\section{The Large Store Law}

The regulation that bears most directly on the density of retail stores in Japan is the Large Store Law. It is the essential reason why Japan, at least historically, has far fewer department stores and general merchandise super stores, and far more of most other kinds of stores, per person than the United States. McCraw and 0' Brien (1986) were early recognizers of this.

Bureaucratic obstacles have been placed on establishment of large stores since the Department Store Act of 1937. Suspended in 1947 but reinstated in 1956, it required approval of the national government for the opening of new department stores anywhere in Japan. In 1974 the Large Scale Retail Store Law replaced the Department Store Act. It made the extent of floor space, rather than the nature of the store, the criterion for necessitating approval. The cut-off was $3000 \mathrm{~m}^{2}$ in the largest cities and $1500 \mathrm{~m}^{2}$ everywhere else. At the time, almost all stores larger than the cut-offs were department stores. In 1978 the law was completely revamped to broaden coverage to include all new stores over $500 \mathrm{~m}^{2}$, which meant it would apply to many grocery stores.

The process of securing approval to open a large store was torturous, typically requiring two years or longer. The process, directed by the Ministry of International Trade and Industry (MITI), involved hearings before local panels that included owners of existing stores that would suffer if the proposal was approved. The panels tended either to recommend against approval or propose restrictions on the hours or days the store could operate. In many cases they proposed such onerous requirements as requiring offering of classes in cultural activities such as calligraphy or floral arrangement at prices that did not cover costs. MITI tended to adopt these recommendations and proposals. Larke (1994) offers further detail on the process.

Unsurprisingly, following adoption of the 1978 amendments, applications to

\footnotetext{
3 In Nariu and Flath (1993, p 94 table 6-3) we present an OLS regression. Number of steps in Japanese wholesale industry $=$ $0.30+$

0.60 (number of steps in matching US wholesale industry) +

0.09 (stores per household in Japan divided by stores per household in in the US for retail category corresponding to the wholesale industry). $(\mathrm{t}-$ stat $=4.1),(\mathrm{t}-\mathrm{stat}=3.3) ;$ number of observations $=24 ; \mathrm{R} 2=0.57$.
} 
open new stores dropped to a trickle: in 1984 there were fewer than 500.

In 1989, the US government identified the Large Store Law as a "structural impediment" to the sale of US-made consumer products in Japan, arguing in negotiations with Japan for repeal or relaxation of the law. Japan responded first by amending the law in 1992 to shorten the process for reviewing applications then, in 1994, by raising the cut-off to $1000 \mathrm{~m}^{2}$, which is about one fourth the size of the typical US grocery store.

As shown in Table 5, the number of large stores in operation did increase after 1994. However the overall number remains low compared to the United States. In 1997 there were only around 24,000 stores in all of Japan larger than $1000 \mathrm{~m}^{2}$.

In May 1998, the Diet replaced the old law with a new one (actually with three new laws) that place details of the regulation of large stores under control of prefectural governments but mandates that they consider only environmental factors such as noise and traffic, not any economic harm to incumbent owners of small stores. The line between environmental factors and economic ones is sufficiently fuzzy that some prefectures may actually enact more severe restraints than existed under the previous regime (though I consider this unlikely). Other prefectures may remove the restraints on large stores altogether.

\section{Regulatory Distortions}

Regulatory distortions definitely exist in Japan's distribution sector. Table 6 summarizes them.

The sparseness of large stores clearly is the result of regulations. Restricting the number of large stores may have had a secondary, distorting effect on Japan' s foreign trade insofar as imported consumer products until the 1990s were mostly products more effectively distributed through large, upscale department stores such as Mitsukoshi and Takashimaya.

The multiple wholesale steps and disproportionately large employment in wholesaling may in large part also be a secondary effect of the proliferation of small stores, and thus an indirect result of regulatory protection of small stores. For example, Nariu and Flath (1993) offer a regression equation linking multiplicity of wholesale steps and proliferation of stores.

Regulations regarding inward foreign direct investment (FDI) may have had a relatively large effect on distribution. A disproportionately large share of FDI in Japan (and elsewhere) is in wholesaling. Japan' s vanishingly small stock of inward FDI in comparison with the United States and EU has been linked to Japanese government restrictions relaxed around 1980. The relative absence of foreign-affiliate wholesalers in Japan could inhibit competition and protect inefficient domestic incumbent producers and distributors. (For a close investigation of FDI in Japan' s wholesale industry and its effects on import penetration, see Flath 2001.)

Enforcement also matters. Vertical restraints are often presumptively in violation of the antimonopoly law of Japan, but they nonetheless appear to be widespread. Penalties for violations are notoriously weak and the resources devoted to enforcement are quite parsimonious.

Large stores do not necessarily compete only with small ones: they also complement them, perhaps offering agglomeration economies. In other words, there 
are possible negative effects on small stores from regulatory limits on large ones. Empirical analysis is needed here.

\section{1 Evidence Regarding Regulatory Distortion}

As a first pass at assessing whether the distorting effects of these regulations might be significant, consider some data from McKinsey Global Institute (2000). The authors construct estimates of value-added per hour of labor across stores of different kinds in Japan and the United States in the mid 1990s. They conclude that traditional "papa-mama" stores in Japan have lower average labor productivity than do large stores in Japan and that they account for a disproportionately large share of total labor input compared to the United States (Table 7).

Overall average labor productivity in Japan' s retail sector is only about half that of the United States. Closing that gap would increase Japan' s GDP measurably. How much? Here is a rough calculation. Suppose, for the sake of argument, that only regulatory barriers limit the number of general merchandise stores and supermarket groceries, and that eliminating those barriers would double the labor hours that each group employed in 1997 (to roughly match the US pattern), shifting workers from traditional stores. Also suppose that as this occurred, value-added in traditional stores fell in proportion to the withdrawal of labor, while value-added in other stores remained unchanged as wages displaced their profits. Each year this would eliminate a deadweight loss equal to about $0.25 \%$ of Japanese GDP. ${ }^{4}$

Now suppose further that as a result of the changes in retailing, Japan' $s$ wholesale sector also evolved to more resemble US wholesaling in terms of labor productivity. Employment would fall by $2 \%$ to $4 \%$ of the labor force, freeing millions of workers for employment elsewhere in the economy.

If this thought experiment holds any validity, the distortions afflicting Japan's distribution sector are enormous. But the calculation is highly suspect.

Set aside the obvious difficulties in measuring labor hours and productivity in small, family-operated stores. The calculation accepts that any differences between Japan and the United States in allocation of labor across store types and between the retail and wholesale sectors are wholly the result of distortions and could be eliminated by an act of government policy. If this were true, then large stores of Japan ought to be immensely profitable. They are not. The bankruptcies of the Sogo department store chain and MyCal supermarket chain are reminders of this fact.

\section{2 Vehicle Inspections}

Although the analysis to follow suggests that the distorting effects of the Large Store Law may have been less than often supposed, it also indicates that regulations not specifically focused on that sector may have a distorting effect. Regulations that unnecessarily or wastefully increase the cost of owning and operating a private

4 If labor hours in general merchandise stores and supermarkets doubled from the 1997 levels with no change in value-added (as wages displaced profits), value-added per hour would fall by half in each. The deadweight loss thus eliminated equals the area of a Harberger triangle with right sides equal to the initial labor hours and half the initial value-added per labor hour. In other words, the recovery of deadweight losses amounts to about $25 \%$ of initial value-added: $0.25(2.2+3)=1.3$ trillion yen, which is around $0.25 \%$ of Japan's GDP. 
car indirectly favor small stores over large ones by enhancing household willingness to pay for proximity to stores.

Japan does indeed have such a regulation, the requirement that private car owners submit their vehicles to comprehensive inspections every two years beginning with the car's third year on the road. These vehicle inspections (shaken, in Japanese) are made unnecessarily expensive by the limited number of shops licensed to conduct them and by the onerous requirement that numerous working parts be replaced if an older car is to pass (Beck 1993). This is widely cited as the reason why the average vehicle age in Japan is 5.8 years compared to 8.3 years in the United States, and the average annual mileage per car in Japan is only about half that of the US (JETRO 2002).

As recently as 1990 Japan had a mere 291 cars per thousand persons. As a first pass at assessing whether increasing car ownership may have run its course, consider a simple regression of cars per thousand persons on GNP per person in purchasing power units, using 1998 data. The predicted value for Japan is 450. 1, while the actual number is 395.1 . The $12 \%$ difference is not statistically significant. ${ }^{5}$

My guess is that a further dramatic increase in car ownership in Japan is unlikely, but a lagged response of retail structure to the past increase in car ownership may still play out over the coming decade and beyond.

\section{Retail Formats}

Japanese statistics define eight store formats (Table 8). Format is determined by whether a store is self-service and by the mix of merchandise it offers in three broad categories (clothing, food, and living (jun-kanren)).

Large stores are primarily department stores, general merchandise super stores, and specialty super stores. Similarly, these formats tend to be large stores. The essential difference between general merchandise super stores and department stores is that the former are self-service stores while the latter are not.

Table 9 provides time-series on the numbers and average scale of stores in each format. Note the 1997 changes in the definitions of specialty super stores and convenience stores. Before 1997, the specialty super store category included stores larger than $500 \mathrm{~m}^{2}$, which meant they were all subject to the Large Store Law. Then, stores as small as $250 \mathrm{~m}^{2}$ were reclassified from other super stores to specialty super stores if their product-mix concentration met the specialty requirement. This tripled stores in the category. Department stores and general merchandise super stores have decreased in number from 1997 to 1999, their travails documented in numerous news accounts.

There is no category for small family-owned stores as such: most are either specialty or semi-specialty stores. Two-thirds of them are sole proprietorships. 0n1y 5\% of specialty super stores are sole proprietorships and no large stores is.

Between $5 \%$ and $10 \%$ of specialty and semi-specialty stores are contained within the premises of large stores (that is boutiques within larger stores). The total

\footnotetext{
5 The $\log$ linear OLS regression is:

ln $($ cars per thousand $)=$

$-2.9+0.9 \ln$ (GNP in PPP units) - 0.13 (dummy equal to one for Japan)

$(\mathrm{t}-\mathrm{stat}=6.6)(\mathrm{t}-\mathrm{stat}=0.5) ;$ number of observations $=26 ; \mathrm{R} 2=0.65$.
} 
number of such stores (not themselves large but, contained within the premises of ones that are large) has remained around 100,000 since 1991.

Table 10 shows the time-series for composition of total sales across the types of store. These data reflect the same trends in numbers of stores.

\section{1 Influences on the Number of Stores by Format}

The Large Store Law has limited the number of stores with large floor space. Almost all of these are department stores, general merchandise super stores, or specialty super stores. The law also ought to have induced increased numbers of stores of other formats. These include small family-owned, non-self service stores that are mostly classified as specialty stores or semi-specialty stores. Our next task is to measure these effects.

In measuring the effect of regulatory change on the number of stores, it is necessary to control for changes in other factors influencing retail density. These include increasing ownership of passenger cars, increasing average space per person in dwellings, and declining population density in cities as the suburbs expand. Increasing car ownership favors evolution towards a retail sector with fewer, larger stores. Declining population density per se has the opposite effect on retail density but is probably itself an inevitable accompaniment of the move toward car ownership and larger dwellings. All three trends can be placed under the heading "suburbanization". Tables 11, 12, and 13 document them.

More living space means that storage space is less constrained, enabling households to shop less frequently for daily necessities and to maintain larger stocks, eroding the value to households of proximity to stores selling nondurables. The effect of larger, less crowded dwellings on the numbers of stores selling durables is possibly the opposite, leading to more such stores. But stores selling nondurables

such as food and daily necessities are more numerous than the ones selling durables such as furniture.

As population density becomes less, the marginal benefit to households of a proliferation of stores becomes greater. This effect arises because, as households are more diffuse, any given number of stores per household entails a greater average distance from each household to the nearest store, and the reduction in that distance with each given increase in number of stores becomes correspondingly greater. See Flath (1990) for an algebraic treatment of this phenomenon. The point here is that the gradual decline in average population density that has accompanied the proliferation of cars and increased spaciousness of dwellings has possibly in and of itself slowed the push towards fewer, larger stores in Japan.

\section{Results from Analyzing Prefectural Differences}

Regulatory effects should vary among prefectures because, although a national statute, the Large Store Law was implemented through locally administered advisory panels in each municipal jurisdiction. To measure these regulatory effects, I ran a set of regressions (detailed in Box 1). The results are in Table 14. 
To explain the numbers of stores per person of different kinds, I ran OLS regressions using data for each of Japan's 47 prefectures from five consecutive Census of Commerce of Japan $(1985,1988,1991,1994$, and 1997). The dependent variable is the natural $\log$ of the number of stores per 1000 persons. There is a different equation for each different format of store and for all stores.

The independent variables are the same in each equation and as in Matsui and Nariu (2001) include a dummy variable for each prefectures. I do not report the estimates of coefficients on these dummies.

The independent variables of interest include the natural logs of the three variables being discussed, observed for each prefecture: passenger cars per 1000 persons, dwelling floor space per person, and 1000 persons per $\mathrm{km}^{2}$ in densely inhabited districts. To further control for the diffusion of population, I included the fraction of each prefecture' s population residing in densely inhabited districts. It was necessary to log linearly interpolate between, or extrapolate from, housing census years and population census years respectively. Annual data are available for passenger car registrations.

The natural logarithms of the number of Class 1 large stores and of Class 2 large stores are included to measure the severity of regulation of large stores. So, for example, after 1994, large stores with floor space between $500 \mathrm{~m}^{2}$ and $1000 \mathrm{~m}^{2}$ were automatically approved by MITI, but in the Census of Commerce these were still classified as "large stores".

An examination of the first column estimates in Table 14 reveals that car ownership and urban population density have influenced the overall density of stores in the expected way. Disappointingly, size of dwelling has not exerted a statistically significant effect on overall density of stores (nor a coherent effect on numbers of stores of particular formats).

The number of Class 1 large stores (floor space of $3000 \mathrm{~m}^{2}$ or more, except in the central parts of major cities where it is $6000 \mathrm{~m}^{2}$ or more, and a proxy for regulation) has no measurable effect on the overall number of stores. However, the density of Class 2 large stores (those that are not class 1, and another proxy for regulation) is, as expected, inversely related to the overall number of stores. Possibly this reflects the much greater temporal variation in the number of Class $2 \mathrm{~s}$ than in Class 1s (shown in Table 5).

All of the variables, including the number of Class $2 \mathrm{~s}$, have inelastic effects on the overall number of stores. Over the period 1985-97 the number of Class $2 \mathrm{~s}$ grew about $5 \%$ per year, while the overall number of stores shrank about $1.1 \%$. Given the estimated elasticity of overall number of stores with respect to number of Class $2 \mathrm{~s}$ of -0.10 , expansion of these large stores by itself accounts for a little less than half of the constriction in overall number of stores.

Relaxed regulation is a contributing factor to reduction in number of stores, slightly less important than increasing car ownership. The inelasticity of overall number of stores with respect to number of (Class 2) large stores $(=-0.10)$ generally argues against regulatory limits on large stores as being in any way crucial in explaining the proliferation of small stores. For example, quadrupling or quintupling the number of class 1 and class 2 stores would roughly match the density of such stores per person in the United States, but based on these estimates would still not dramatically reduce the overall number of stores in Japan. 
If regulation mattered greatly, one would expect that in prefectures where the large store law was more loosely applied, overall retail density would be dramatically smaller than elsewhere. This does not appear to have been the case.

Fundamentals, including those embedded in the prefecture by prefecture fixed effects, account for far more of the variation in overall density of stores both across prefectures and over time than does the regulatory-determined number of large stores.

The influences of the regulation variables and car ownership on density of stores of each format further instill confidence in the economic model underlying the specification and the interpretation of results just offered. The positive influence of the regulation-determined number of Class 1 large stores on the number of department stores is evident, as is the positive influence of the number of Class 2 large stores on the number of general merchandise super stores and specialty super stores. This comports with the fact that most of the department stores have very great floor space and so are in Class 1.

Car ownership is generally undercutting specialty stores and semi-specialty stores and promoting convenience stores, department stores and self-service (that is, super) stores of all kinds. The very large and positive influence of increasing car ownership on the number of convenience stores may be an important reason for their recent very rapid growth.

The size of the effect of car ownership on overall number of stores shown in Table 11 (elasticity=-0.17) is quite a bit less than in the cross-country regression of Table 4 (elasticity $=-0.3$ ) (The larger coefficient estimate, -0.6 , from Table 4 is perhaps biased by exclusion of the variable CRWDNG pertaining to size of dwelling. ) There is a simple explanation for this: The regulatory limit on the number of large stores in Japan is dampening the response of number of stores to increasing car ownership.

If this is true, then it suggests a way of quantifying the likely ultimate effect of deregulation on the overall number of stores: It might be roughly equivalent to the effect of doubling the responsiveness of overall numbers of stores to increased car ownership from an elasticity of 0.17 to 0.30 . That is, one might expect the overall number of stores in Japan ultimately to fall by about 15\% from its 1997 level (11.3 per thousand persons) to around 9.6 per thousand.

The picture that emerges is one that matches the earlier analysis of international data; regulatory distortions account for little in explaining Japan' s high density of stores.

\section{Conclusion}

The Japanese distribution sector certainly exhibits peculiarities. It has vastly more stores per person than most other rich countries. It also has particularly complex wholesale marketing channels, with multiple steps and ubiquitous vertical restraints. This chapter has explored the reasons and found them to relate more to economics than to regulation. It also has shown how the peculiarities are complementary.

Scarcity of living space and the inconvenience of owning and operating a car has enhanced Japanese households' willingness to pay for nearby shopping. Japan's geographic centricity has facilitated development of a transport system and complex logistical arteries that lower the costs of continually restocking the many retail outlets. These factors combine to make a proliferation of stores in Japan not only 
inevitable but efficient. Given this, regulations protecting small stores from competition by large ones (mostly in the form of the Large Store Law and its successor, the Large Store Location Law) imply only minor economic distortions and encounter little effective political resistance. But as car ownership has grown, the distorting effects of regulations limiting large stores have become greater and politically less tenable.

A proliferation of small stores increases the economic advantages of logistical arteries with many branches, which in turn lowers the costs of a multiplicity of wholesale steps. The implied ubiquity of retailers and wholesalers increases the horizontal externalities that arise in promoting and marketing goods and that are the target of vertical restraints such as customer assignments and exclusive dealing stipulations. The distortions that are an unwanted consequence of these sorts of stipulations lead to further manufacturer- and wholesaler-initiated stipulations on pricing and shipment quantities, which are tolerated by $\operatorname{lax}$ enforcement of antimonopoly laws.

Some of the fundamental forces accounting for Japan' s proliferation of small stores are changing. For example, car ownership increased dramatically during the 1990s and the average size of dwelling also is steadily increasing. Probably as a result, in the 1990s grocery supermarkets and general merchandise super stores increased in number in Japan even as the overall number of stores steadily declined. Changes in implementation of the Large Store Law introduced in 1994 and its ultimate repeal and replacement with the Large Scale Retail Store Location Law in 2000 also have contributed to changes in the number and composition of Japan's stores.

Government policies shape the economy, but the reverse also is true. Regulations emerge from a political process in which economic forces operate (Becker 1983). In Japan as elsewhere, the economy has shaped regulations, and regulation has reinforced inherent tendencies rather than fundamentally altered them. 


\section{References}

Beck, John C. (1993). “Japanese Consumers as Battering Rams: Can They Break Down the Non-Market Entry Barriers to Japan’ s Auto Aftermarket Industry?” in Michael R. Czinkota and Masaaki Kotabe, eds., The Japanese Distribution System, pp. 281-94, Chicago: Probus Publishing Company.

Becker, Gary (1983). “A Theory of Competition Among Pressure Groups”, Quarterly Journal of Economics, vol. 98, pp. 371-400.

Boylaud, Olivier and Giuseppe Nicoletti (2001). "Regulatory Reform in Retail Distribution”, OECD Economic Studies, no. 32, pp. 253-274.

Chuushou kigyou chou, tsuushou sangyou daijin kanbou chousa toukei bu (Small and Medium Enterprise Agency, Ministry of International Trade and Industry, Minister' s Secretariat, Research and Statistics Department) (1994). Waga kuni ni okeru shougyou kigyou no hensen to genkyou, saikin 20 nen ni okeru shougyou jittai kihon chousa o tsuujite (Variation and current state of Japanese retail and wholesale enterprises, through the most recent 20 years of the basic survey of retail and wholesale enterprises), Tokyo: Tsuusan toukei kyoukai.

Flath, David (2000). The Japanese Economy, Oxford U press.

Flath, David (1989). "Vertical Restraints in Japan," Japan and the World Economy, 1: $187-203$.

Flath, David (1990). "Why Are There So Many Retail Stores in Japan?" Japan and the World Economy, 2: 365-386.

Flath, David (2001). "Japanese Distribution Keiretsu, FDI and Import Penetration" , mimeo.

Flath, David and Tatsuhiko Nariu (1996). "Is Japan's Retail Sector Truly Distinctive?" Journal of Comparative Economics, 2:181-191.

Gabszewicz, Jean Jaskold and Jacques-Francois Thisse (1986). "Spatial Competition and the Location of Firms", in J. Gabszewicz et al, ed., Location Theory, New York, NY: Harwood Academic, pp. 1-7.

Heal, Geoffrey (1980). "Spatial Structure in the Retail Trade: A Study of Product Differentiation with Increasing Returns” , Bell Journal of Economics, vol. 11, pp. 565-583.

Ito, Takatoshi and Maruyama, Masayoshi. (1991). "Is the Japanese Distribution System Really Inefficient?” in Paul Krugman, ed., Trade with Japan: Has the Door Opened Wider?, University of Chicago Press, NBER, pp. 149-74.

JETRO (2002). "The Survey on Actual Conditions Regarding Access to Japan: Replacement Auto Parts" (March)...posted on the JETRO web site.

Maruyama Masayoshi, et al. (1991). Nihon no ryuutsuu shisutemu: riron to jissho (The distribution system of Japan: theory and empirics), Keizai Bunseki, vol. 123 (May).

McKinsey Global Institute (2000) "Why the Japanese Economy is not Growing: micro barriers to productivity growth,” July.

Milgrom, Paul and John Roberts (1995). "Complementarities and Fit: Strategy, Structure, and Organizational Change in Manufacturing” , Journal of Accounting and Economics, vol. 19, pp. 179-208.

Miwa, Yoshirou and Mark Ramseyer (2002), The Japanese Distribution System, Oxford University Press.

Nariu Tatsuhiko (1994). Ryuutsuu no keizai riron (The economic theory of marketing), Nagoya shuppankai.

Nariu, Tatushiko and David Flath (1993). "The Complexity of Wholesale Distribution Channels in Japan," in Michael R. Czinkota and Masaaki Kotabe, eds., The Japanese Distribution System, pp. 83-98, Chicago: Probus Publishing Company. 
Matsui, Kenji and Tatushiko Nariu (2001). "Panel Data Analysis of the Density of Retail Stores in Japan", working paper, faculty of economics, Kyoto University.

OECD (2000). "Assessing Barriers to Trade in Services: Retail Trade Services", working party of the trade committee.

OECD, Regulation Database --downloadable from OECD website.

Pilat, Dirk (1997). "Regulation and Performance in the Distribution Sector" , OECD Economics Department Working Papers, no. 180.

Soumushou toukei kyoku, toukei kenshuu jou (statistics bureau, statistics study center (ministry of public management, home affairs, posts and telecommunications, govt of Japan)), Sekai no toukei 2001 (Statistics of the world 2001).

Tsuushou sangyou daijin kanbou chousa toukei bu (Ministry of International Trade and Industry, Minister's Secretariat, Research and Statistics Department), Heisei kyuunen Shou gyou toukei hyou (1997 Census of Commerce).

United Nations Statistics Division, "Social Indicators" homepage.

World Bank (2001), World Development Report 1999/2000, 0xford University Press. 
Table 1

Features of the Japanese Distribution System

\begin{tabular}{|c|c|c|}
\hline $\begin{array}{l}\text { United } \\
\text { States }\end{array}$ & Japan & Indicator \\
\hline \multicolumn{3}{|l|}{ Small stores } \\
\hline 6.1 & 11.2 & Stores per 1000 persons (US 1996, Japan 1997) ${ }^{1}$ \\
\hline 11.7 & 5.1 & Workers per store (US 1992, Japan 1997) \\
\hline a31, 830 & 18,709 & $\begin{array}{l}\text { Number of typical supermarkets (in Japan, called food } \\
\text { specialty super stores) (US 2000, Japan 1999) }{ }^{2}\end{array}$ \\
\hline${ }^{\mathrm{b}} 4,143$ & 832 & Average store's floor space in m2 (US 2000, Japan 1999)2 \\
\hline$\$ 12$ & $¥ 895$ & $\begin{array}{l}\text { Average store's annual sales in million (US 2000, Japan } \\
1999)^{2}\end{array}$ \\
\hline \multicolumn{3}{|c|}{ Long and Complex Wholesale M } \\
\hline & & Percentage of labor force employed in: \\
\hline 4.1 & 8.0 & Wholesaling (1990-93) \\
\hline 3.8 & 5.9 & Wholesaling (1996-97 Japan, 1997 US) \\
\hline 11.4 & 10.4 & Retailing (1993) \\
\hline 10.9 & 11.2 & Retailing (1996-97 Japan, 1997 US) \\
\hline 25 & 42 & $\begin{array}{l}\text { Percentage of wholesale sales to other wholesalers: }{ }^{3} \\
1985-86\end{array}$ \\
\hline . & 5 & 1997 \\
\hline
\end{tabular}

Notes and sources: Data are from Table 2 except as indicated.

1 The UK had 3.4 in 1994

2 Census of Commerce of Japan and (US) Food Marketing Institute.

3 Census of Commerce of Japan and (for US) Ito and Maruyama 1991

a Stores with annual sales of $\$ 2$ million or more.

b 44,600 ft2, which is slightly smaller than a US football field. 
Table 2

International Comparison of Distribution Sectors

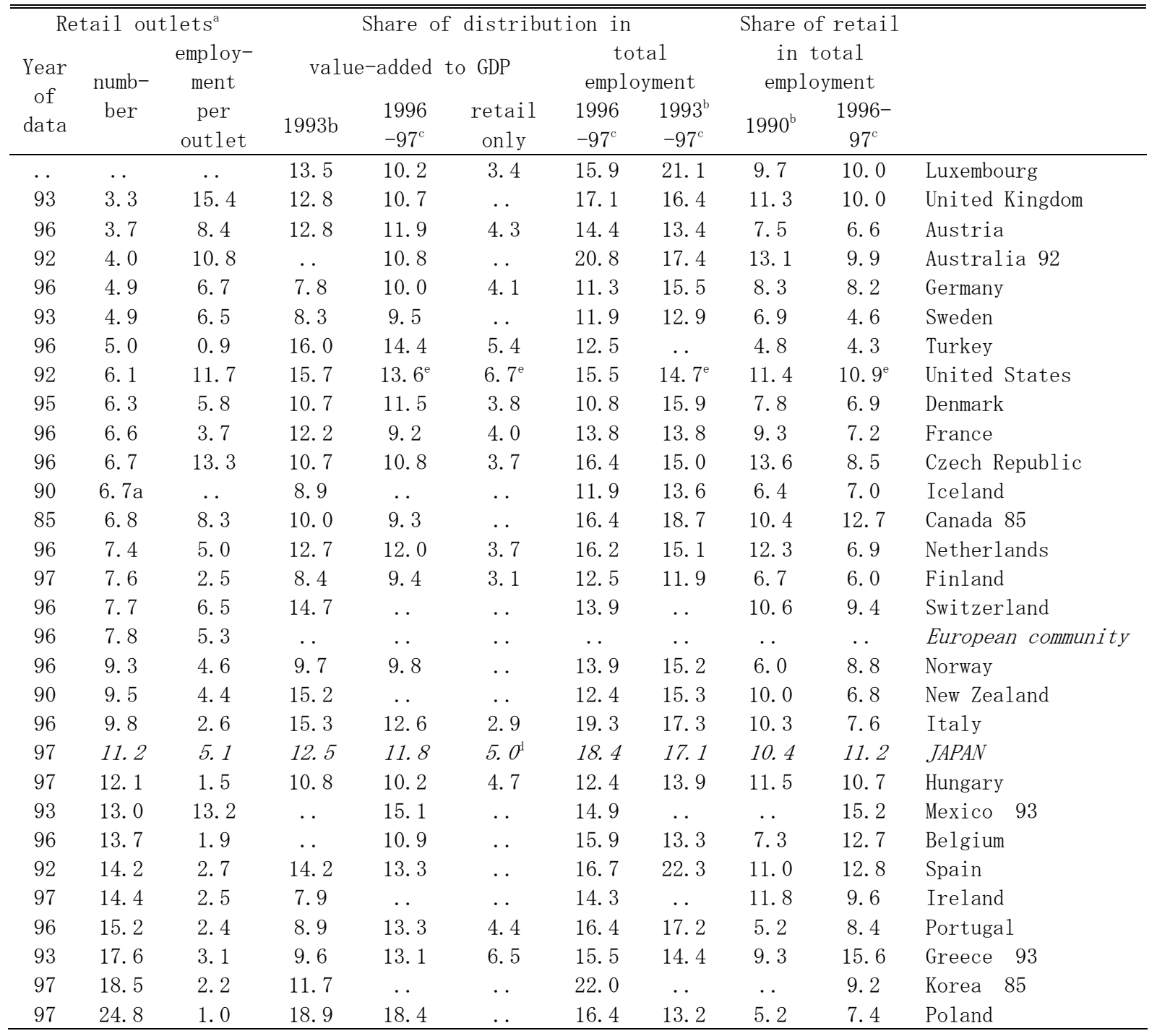

1 Value added to GDP by retail sector.

Sources:

a OECD Regulation Database except as noted.

b Pilat (1997), Table 2.1, p. 17.

c Boylaud and Nicoletti (2001), Table 1, p. 256.

d McKinsey Global Institute (2000), (Retail(, exhibit 1.

e Statistical Abstract of the United States 
Table 3

Factors in Retail Density, $1998^{1}$

\begin{tabular}{|c|c|c|c|c|c|c|c|c|}
\hline STORES & CRWDG & CARS & URBAN & LENGTH & TRUCKS & GNPPP & GNP & Variable $^{8}$ \\
\hline $\begin{array}{c}\text { Store } \\
\text { den- }^{-} \\
\text {sity }^{2}\end{array}$ & $\begin{array}{c}\text { Crowd- } \\
\text { ing }^{3}\end{array}$ & $\begin{array}{l}\text { Car } \\
\text { den- } \\
\text { sity }^{4}\end{array}$ & $\begin{array}{c}\text { Urban- } \\
\text { iza- }^{-} \\
\text {tion }^{5}\end{array}$ & Length $^{6}$ & $\begin{array}{c}\text { Truck } \\
\text { den- }^{-} \\
\text {sity }^{4}\end{array}$ & $\begin{array}{c}\text { GNP } \\
(\mathrm{PPP})^{7} \\
(\mathrm{US} \$)\end{array}$ & $\begin{array}{l}\text { GNP } \\
\text { per cap } \\
\text { (US\$) }\end{array}$ & Country \\
\hline 0.5 & $3.4^{\mathrm{a}}$ & 374.2 & 89 & 15.7 & 47.1 & 20,640 & 21,400 & Utd Kingdom \\
\hline $0.6^{\mathrm{b}}$ & 3.7 & 479.9 & 65 & 9.2 & 38.3 & 22,740 & 26,850 & Austria \\
\hline & 4.0 & 472.3 & 85 & 88.0 & 110.5 & 20,130 & 20,300 & Australia \\
\hline 0.5 & 4.9 & 507.6 & 87 & 18.9 & 28.9 & 20,810 & 25,850 & Germany \\
\hline $0.6 \mathrm{~b}$ & 4.9 & 426.1 & 83 & 21.2 & 38.0 & 19,480 & 25,620 & Sweden \\
\hline 1.3 & $5.1 \mathrm{a}$ & 63.8 & 73 & 27.8 & 15.7 & . & 3,160 & Turkey \\
\hline 0.5 & $5.8 \mathrm{a}$ & 480.6 & 77 & 96.8 & 280.9 & 29,340 & 29,340 & United State \\
\hline .. & 6.3 & 354.2 & 86 & 6.6 & 56.2 & 23,830 & 33,260 & Denmark \\
\hline 0.7 & 6.6 & 455.8 & 75 & 23.5 & 92.1 & 22,320 & 24,940 & France \\
\hline & 6.7 & 510.9 & 92 & 10.1 & 62.0 & 22,830 & 28,010 & Iceland \\
\hline 0.5 & 6.8 & 440.8 & 77 & 99.9 & 121.2 & 24,050 & 20,020 & Canada \\
\hline 1.0 & $6.8 \mathrm{a}$ & 358.0 & 66 & 8.9 & 41.1 & . . & 5,040 & Czech Rep \\
\hline 0.7 & 7.4 & 566.3 & 89 & 6.4 & 100.6 & 21,620 & 24,760 & Netherlands \\
\hline $0.7 \mathrm{~b}$ & 7.6 & 388.7 & 64 & 18.4 & 54.0 & 20,270 & 24,110 & Finland \\
\hline 0.6 & 7.7 & 476.5 & 62 & 6.4 & 37.6 & 26,620 & 40,080 & Switzerland \\
\hline 0.6 & 9.3 & 405.9 & 74 & 18.0 & 88.9 & 24,290 & 34,330 & Norway \\
\hline 0.5 & 9.5 & 440.5 & 87 & 16.5 & 99.7 & 15,840 & 14,700 & New Zealand \\
\hline $0.8 \mathrm{~b}$ & 9.8 & 538.2 & 67 & 17. 3 & 50.7 & 20,200 & 20,250 & Italy \\
\hline $0.6 \mathrm{~b}$ & $11.2 \mathrm{a}$ & 395.1 & 79 & 19. 4 & 163.8 & 23,180 & 32,380 & JAPAN \\
\hline 0.5 & 12.1 & 234.2 & 66 & 9.6 & 32.2 & . . & 4,510 & Hungary \\
\hline 1.4 & 13.0 & 97.8 & 74 & 44.2 & 45.9 & 8,190 & 3,970 & Mexico \\
\hline $0.5 \mathrm{~b}$ & 13.7 & 437. 1 & 97 & 5.7 & 45.0 & 23,480 & 25,380 & Belgium \\
\hline $0.7 \mathrm{~b}$ & 14.2 & 389.2 & 77 & 22.5 & 81.6 & 16,060 & 14,080 & Spain \\
\hline . & 14.4 & 266.8 & 58 & 8.4 & 31.1 & 18,340 & 18,340 & Ireland \\
\hline 0.7 & 15.2 & 308.0 & 61 & 9.6 & 36.3 & 14,380 & 10,690 & Portugal \\
\hline . & 17.6 & 254.9 & 60 & 11.5 & 93.2 & 13,010 & 11,650 & Greece \\
\hline 1.1 & 18.5 & 163.4 & 84 & 10.0 & 46.1 & 12,270 & 7,970 & Korea \\
\hline 2.0 & 24.8 & 229.7 & 65 & 18.0 & 40.8 & 6,740 & 3,900 & Poland \\
\hline
\end{tabular}

Notes and Sources.

1 Or nearest year for which data are available.

2 Stores per 1000 inhabitants. (Table 2, except as noted.)

3 Rooms per person. United Nations Statistics Division, social indicators homepage, (except as noted).

4 Such vehicles per 1000 inhabitants. (Somusho tokei kyoku 2001, Table 8-2.)

5 Urban population as percentage of total. (World Bank 2001, p 232 Table 2.)

6 Square root of the country's area (1000km(). (World Bank 2001, p 232 Table 2.)

7 GNP per capita adjusted to purchasing power parity.

8 Name of variable in regression analysis.

a Using data from Boylaud and Nicoletti (2001) p 256 Table 1: Czech Rep, Japan, Turkey are 1997; United Kingdom is 1994; United States is 1996.

b Somusho tokei kyoku 2001, p 296 Table 13-6 (rooms per dwelling) divided by p 32 Table 2-10 (persons per household). 
Table 4

OLS Regressions Explaining International Variation in Density of Stores

Dependent variable $=1 \mathrm{n}$ STORES

Coefficients, with t-statistics in parentheses

\begin{tabular}{|c|c|c|c|c|}
\hline With CR & $\begin{array}{l}\text { VDNG } \\
\text { Japan } \\
\text { excluded }\end{array}$ & Without & $\begin{array}{l}\text { CRWDNG } \\
\text { Japan } \\
\text { excluded }\end{array}$ & Variable: \\
\hline $\begin{array}{l}3.4 \\
(1.9)\end{array}$ & $\begin{array}{l}3.5 \\
(1.8)\end{array}$ & $\begin{array}{l}5.6 \\
(5.2)\end{array}$ & $\begin{array}{l}5.6 \\
(5.1)\end{array}$ & Constant \\
\hline $\begin{array}{l}-0.4 \\
(-0.4)\end{array}$ & $\begin{array}{l}-0.4 \\
(-0.4)\end{array}$ & $\begin{array}{l}-1.4 \\
(-1.7)\end{array}$ & $\begin{array}{l}-1.4 \\
(-1.7)\end{array}$ & URBAN \\
\hline $\begin{array}{l}-0.3 \\
(-1.0)\end{array}$ & $\begin{array}{l}-0.3 \\
(-1.0)\end{array}$ & $\begin{array}{l}-0.6 \\
(-2.9)\end{array}$ & $\begin{array}{l}-0.6 \\
(-2.8)\end{array}$ & In CARS \\
\hline $\begin{array}{l}0.5 \\
(2.1)\end{array}$ & $\begin{array}{l}0.5 \\
(1.9)\end{array}$ & $\begin{array}{l}0.5 \\
(2.6)\end{array}$ & $\begin{array}{l}0.5 \\
(2.4)\end{array}$ & 1n TRUCKS \\
\hline $\begin{array}{l}-0.3 \\
(-2.0)\end{array}$ & $\begin{array}{l}-0.3 \\
(-1.9)\end{array}$ & $\begin{array}{l}-0.4 \\
(-2.8)\end{array}$ & $\begin{array}{l}-0.4 \\
(-2.8)\end{array}$ & ln LENGTH \\
\hline $\begin{array}{l}0.6 \\
(1.5)\end{array}$ & $\begin{array}{l}0.6 \\
(1.5)\end{array}$ & - & - & 1n CRWDG \\
\hline $\begin{array}{c}23 \\
0.40\end{array}$ & $\begin{array}{c}22 \\
0.39\end{array}$ & $\begin{array}{c}28 \\
0.40\end{array}$ & $\begin{array}{c}27 \\
0.41\end{array}$ & $\begin{array}{l}\text { Number of obsevarvations } \\
\mathrm{R}^{2}\end{array}$ \\
\hline - & $\begin{array}{l}11.8 \\
(0.08)\end{array}$ & - & $\begin{array}{l}11.7 \\
(0.13)\end{array}$ & $\begin{array}{l}\text { Predicted value of STORES for Japan } \\
\text { t-test statistic for difference from } \\
\text { actual value (11.3) }\end{array}$ \\
\hline
\end{tabular}


Table 5

Number of Large Stores in Japan, 1985-99

\begin{tabular}{ccccccccc}
\hline \hline & \multicolumn{3}{c}{ Large stores } & \multicolumn{3}{c}{ Al1 stores } \\
& class $1^{1}$ & \multicolumn{2}{c}{ class $2^{2}$} & total & \multicolumn{2}{c}{ total } \\
& & $\%^{3}$ & & $\%^{3}$ & & $\%^{3}$ & & $\%^{3}$ \\
\hline 1985 & 3,662 & - & 9,624 & - & 13,286 & - & $1,628,644$ & - \\
1988 & 4,027 & 3.2 & 10,605 & 3.3 & 14,632 & 3.3 & $1,619,752$ & -0.2 \\
1991 & 4,429 & 3.2 & 11,082 & 1.5 & 15,511 & 2.0 & $1,591,223$ & -0.6 \\
1994 & 3,351 & -8.9 & 14,292 & 8.8 & 17,643 & 4.4 & $1,499,948$ & -1.9 \\
1997 & 4,350 & 9.1 & 17,542 & 7.1 & 21,892 & 7.5 & $1,419,696$ & -1.8 \\
1999 & - & - & - & - & 23,897 & 4.5 & $1,406,884$ & -0.5 \\
\hline
\end{tabular}

1 Class 1 includes larger stores (over $3000 \mathrm{~m} 2$ in most regions, $6000 \mathrm{~m} 2$ in selected wards of Tokyo and other large cities).

2 Class 2 covers remaining large stores. In the 1999 Census of Commerce the distinctions were abandoned.

3 Annual average percentage change since prior census.

Source: Census of Commerce of Japan. 
Table 6

Regulations Distorting Distribution Sector Resource Allocation

\begin{tabular}{|c|c|c|}
\hline Regulation & $\begin{array}{l}\text { Nature of effect on } \\
\text { distribution sector }\end{array}$ & Comment \\
\hline $\begin{array}{l}\text { Large Store Law } \\
1974-2000 .\end{array}$ & $\begin{array}{l}\text { Severely limited number of } \\
\text { stores with large floor space, } \\
\text { including department stores } \\
\text { and general merchandise } \\
\text { super-stores, contributing to } \\
\text { survival of small traditional } \\
\text { stores. }\end{array}$ & $\begin{array}{l}\text { Repealed in } 1998 \text { but in effect until } \\
\text { April } 2000 . \text { Administered by } \\
\text { national government. }\end{array}$ \\
\hline $\begin{array}{l}\text { Large-Scale } \\
\text { Retail Store } \\
\text { Location Law } \\
2000^{-}\end{array}$ & $\begin{array}{l}\text { Enacted with repeal of the } \\
\text { Large Store Law. }\end{array}$ & $\begin{array}{l}\text { Vests prefectures and } \\
\text { municipalities with authority to } \\
\text { limit large stores (1000m } 2 \text { or } \\
\text { greater). Supposedly criteria is to } \\
\text { be confined to environmental } \\
\text { factors such as noise and traffic } \\
\text { only, but skepticism is warranted. }\end{array}$ \\
\hline $\begin{array}{l}\text { Automotive } \\
\text { inspection } \\
\text { (shaken) }\end{array}$ & $\begin{array}{l}\text { The Road Vehicles Act (revised } \\
\text { 1995) mandates comprehensive } \\
\text { safety inspections of private } \\
\text { passenger vehicles every two } \\
\text { years beginning with the third } \\
\text { year the car is in operation. }\end{array}$ & $\begin{array}{l}\text { This usually entails purchase of } \\
\text { numerous replacement parts. The } \\
\text { cost inhibits car ownership and thus } \\
\text { helps perpetuate the advantage of } \\
\text { near-by small neighborhood stores } \\
\text { over larger, more distant stores. }\end{array}$ \\
\hline
\end{tabular}


Table 7

Japan-US Comparison of Retail Stores

\begin{tabular}{|c|c|c|c|c|c|c|c|}
\hline $\begin{array}{l}\text { Total } \\
\text { sector }\end{array}$ & $\mathrm{GMS}^{1}$ & $\begin{array}{l}\text { Super- } \\
\text { markets }\end{array}$ & $\begin{array}{l}\text { Special- } \\
\text { ty } \\
\text { chains }\end{array}$ & $\begin{array}{l}\text { Conven- } \\
\text { ience } \\
\text { stores }\end{array}$ & $\begin{array}{l}\text { Depart- } \\
\text { ment } \\
\text { stores }\end{array}$ & $\begin{array}{l}\text { Tradi- } \\
\text { tionals }\end{array}$ & \\
\hline- & 7 & 7 & 34 & 3 & 10 & 37 & $\begin{array}{l}\text { Share of sales: } \\
\text { Japan } 1988\end{array}$ \\
\hline- & 8 & 12 & 36 & 4 & 9 & 30 & Japan 1997 \\
\hline- & 15 & 24 & 35 & 3 & 7 & 17 & United States 1995 \\
\hline- & 4 & 8 & 23 & 2 & 8 & 55 & $\begin{array}{l}\text { Share of labor hours: } \\
\text { Japan } 1997\end{array}$ \\
\hline- & 14 & 21 & 35 & 3 & 8 & 19 & United States 1995 \\
\hline 25. 5a & 2.2 & 3.0 & 12.0 & 1.0 & 2.0 & 3.0 & $\begin{array}{l}\text { Value-added: } \\
\text { Japan } 1997^{2}\end{array}$ \\
\hline 50 & 106 & 73 & 102 & 96 & 48 & 19 & Per hour Japan $1997^{3}$ \\
\hline 50 & 93 & 60 & 84 & 88 & 70 & 33 & As percentage of US \\
\hline
\end{tabular}

1 Discounters and general merchandise stores.

2 In trillion yen.

3 US retail average $=100$.

a $5 \%$ of GDP.

Source: McKinsey Global Institute (2000), p 27 Exhibit 4, p 28 Exhibit 5. Categories of stores do not correspond exactly to those of the Census of Commerce of Japan. Presumably this is because of the need for correspondence between the types of stores in Japan and the United States. 
Table 8

Store Formats in Japan ${ }^{1}$

\begin{tabular}{|c|c|c|}
\hline Size in $\mathrm{m}^{2}$ & Product mix $^{2}$, other requirements & Category \\
\hline \multicolumn{3}{|c|}{ Self-service ${ }^{3}$} \\
\hline- & $\begin{array}{l}\text { At least } 10 \% \text {, but no more than } 70 \% \text {, of } \\
\text { sales in each category. }\end{array}$ & $\begin{array}{l}\text { General Merchandise super } \\
\text { stores }\end{array}$ \\
\hline$>250^{\mathrm{a}}$ & At 1 east $70 \%$ of sales in a category. & Specialty super stores \\
\hline $30-250^{b}$ & $\begin{array}{l}\text { Includes food. Open at least } 14 \\
\text { hrs/day. }\end{array}$ & Convenience stores \\
\hline- & $\begin{array}{l}\text { Self-service stores not in the other } 3 \\
\text { categories. }\end{array}$ & Other super stores \\
\hline \multicolumn{3}{|c|}{ Non-self-service } \\
\hline- & $\begin{array}{l}\text { At least } 10 \% \text {, but no more than } 70 \% \text {, of } \\
\text { sales in each category. }\end{array}$ & Department stores \\
\hline- & At least $90 \%$ of sales in 1 category. & Specialty stores \\
\hline- & $\begin{array}{l}\text { Between } 50 \% \text { and } 90 \% \text { of sales in } 1 \\
\text { category. }\end{array}$ & Semi-specialty stores \\
\hline- & $\begin{array}{l}\text { Non-self-service stores not in the } \\
\text { other } 3 \text { categories. }\end{array}$ & $\begin{array}{l}\text { Other non-self-severvice } \\
\text { stores }\end{array}$ \\
\hline
\end{tabular}

1 As established by the Census of Commerce of Japan for 1997 and later years.

2 Within three categories: clothing, food, and living (jun-kanren)

3 A store is self-service if at least half the floor space is devoted to sale of merchandise in prepackaged or final form, at a price marked on the product, to customers who move freely about the store with a cart or hand-basket, and who pay no fee to enter the store.

a Before 1997, threshold was $500 \mathrm{~m} 2$.

b Before 1997, range was 50-250m2. 
Table 9

Characteristics of Stores in Japan, 1985-99

\begin{tabular}{|c|c|c|c|c|c|c|}
\hline 1985 & 1988 & 1991 & 1994 & 1997 & 1999 & \\
\hline \multicolumn{7}{|c|}{ A11 Retail Stores } \\
\hline $1,628,644$ & $1,619,752$ & 1, 591, 223 & $1,499,948$ & $1,419,696$ & $1,406,884$ & Number \\
\hline 3.9 & 4.2 & 4.4 & 4.9 & 5.2 & 5.7 & Employees ${ }^{1}$ \\
\hline- & - & 79 & 93 & 105 & 111 & Area $\left(\mathrm{sq} \mathrm{m}^{2}\right)$ \\
\hline 62 & 71 & 88 & 96 & 104 & 102 & Sales ${ }^{2}$ \\
\hline \multicolumn{7}{|c|}{ Department Stores } \\
\hline 438 & 433 & 455 & 463 & 476 & 394 & Number \\
\hline 431 & 446 & 456 & 444 & 392 & 427 & Employees $^{1}$ \\
\hline- & - & 15,063 & 16,340 & 17,133 & 19,134 & Area $\left(\mathrm{sq} \mathrm{m}^{2}\right)$ \\
\hline 17,762 & 20,930 & 25,086 & 22,981 & 22,416 & 24,633 & Sales $^{2}$ \\
\hline \multicolumn{7}{|c|}{ General Merchandise Super Stores } \\
\hline 1,389 & 1,478 & 1,549 & 1,804 & 1,888 & 1,670 & Number \\
\hline 138 & 136 & 142 & 151 & 160 & 192 & Employees ${ }^{1}$ \\
\hline- & - & 5,659 & 6,316 & 7,166 & 8,020 & Area $\left(\mathrm{sq} \mathrm{m}^{2}\right)$ \\
\hline 4,258 & 4,491 & 5,268 & 5,175 & 5,274 & 5,299 & Sales ${ }^{2}$ \\
\hline \multicolumn{7}{|c|}{ Specialty Super Stores } \\
\hline 5,873 & 6,397 & 7,130 & 9,354 & 11,656 & 14,455 & Number \\
\hline- & - & $* 20,827$ & $* 25,171$ & $* 32,209$ & $* 35,531$ & Number $^{3}$ \\
\hline 520 & 571 & 618 & 849 & $* 4,549$ & $* 4,780$ & Clothing \\
\hline 4,707 & 4,877 & 5,185 & 6,231 & $* 17,623$ & $* 18,707$ & Food \\
\hline 646 & 949 & 1,327 & 2,274 & $* 10,037$ & $* 12,044$ & Living \\
\hline 37 & 38 & 37 & 39 & $* 24$ & $* 29$ & Employees ${ }^{1}$ \\
\hline- & - & - & 1,207 & $* 731$ & $* 840$ & Area $\left(\mathrm{sq} \mathrm{m}^{2}\right)$ \\
\hline 983 & 1,000 & 1,122 & 1,115 & $* 635$ & $* 668$ & Sales $^{2}$ \\
\hline \multicolumn{7}{|c|}{ Convenience Stores } \\
\hline 29,236 & 34,550 & 41,847 & 48,405 & 33,167 & 37,025 & Number \\
\hline- & - & $* 23,837$ & $* 28,226$ & $* 36,631$ & $* 39,628$ & Number ${ }^{3}$ \\
\hline 7 & 9 & 8 & 10 & $* 11$ & $* 14$ & Employees ${ }^{1}$ \\
\hline- & - & $* 94$ & *98 & *99 & $* 103$ & Area $\left(\mathrm{sq} \mathrm{m} \mathrm{m}^{2}\right)$ \\
\hline 116 & 145 & 167 & 172 & $* 143$ & $* 155$ & Sales $^{2}$ \\
\hline \multicolumn{7}{|c|}{ 0ther Super Stores } \\
\hline 59,643 & 53,834 & 67,473 & 80,036 & 103,273 & 67,476 & Number \\
\hline- & - & $* 72,027$ & $* 84,878$ & $* 120,721$ & $* 86,367$ & Number ${ }^{3}$ \\
\hline 6 & 7 & 6 & 6 & $* 4$ & $* 6$ & Employees ${ }^{1}$ \\
\hline- & - & - & 128 & *89 & $* 110$ & Area $\left(\mathrm{sq} \mathrm{m}^{2}\right)$ \\
\hline 124 & 144 & 143 & 132 & $* 83$ & $* 98$ & Sales $^{2}$ \\
\hline \multicolumn{7}{|c|}{ Specialty Stores } \\
\hline $1,004,883$ & $1,007,756$ & $1,000,166$ & 930,143 & 839,969 & 920,277 & Number \\
\hline 149,246 & 151,370 & 154,656 & 147,478 & 126,383 & 134,329 & Clothing \\
\hline 290,789 & 293,203 & 283,570 & 263,681 & 230,163 & 249,287 & Food \\
\hline 564,848 & 563,183 & 561,940 & 518,984 & 483,423 & 536,661 & Living \\
\hline 3 & 4 & 4 & 4 & 4 & 5 & Employees ${ }^{1}$ \\
\hline- & - & 53 & 61 & 63 & 63 & Area $\left(\mathrm{sq} \mathrm{m}^{2}\right)$ \\
\hline 47 & 51 & 65 & 66 & 71 & 68 & Sales $^{2}$ \\
\hline \multicolumn{7}{|c|}{ Semi-specialty Stores } \\
\hline 524,885 & 513,338 & 470,289 & 429,108 & 385,748 & 319,685 & Number \\
\hline 74,232 & 78,608 & 76,903 & 65,733 & 62,882 & 54,928 & Clothing \\
\hline 271,593 & 253,352 & 224,756 & 185,509 & 154,736 & 131,465 & Food \\
\hline 177,644 & 179,715 & 166,740 & 175,857 & 168,130 & 133,292 & Living \\
\hline 3 & 3 & 4 & 4 & 4 & 4 & Employees ${ }^{1}$ \\
\hline - & - & 62 & 69 & 74 & 76 & Area $\left(\mathrm{sq} \mathrm{m}^{2}\right)$ \\
\hline 47 & 54 & 67 & 76 & 82 & 75 & Sales $^{2}$ \\
\hline
\end{tabular}

1 Average number per store.

2 Average annual sales in million yen.

3 Using 1997 definitions, for which see text.

Source: Census of Commerce of Japan 
Table 10

Composition of Total Sales Across Formats of Stores, 1985-99.

\begin{tabular}{ccccccl} 
(in percents) \\
\hline \hline 1985 & 1988 & 1991 & 1994 & $1997^{\mathrm{a}}$ & $1999^{\mathrm{a}}$ & \\
\hline 7.6 & 7.9 & 8.1 & 7.4 & 7.2 & 6.7 & Department \\
5.8 & 5.8 & 5.8 & 6.5 & 6.7 & 6.2 & General Merchandise Super \\
5.7 & 5.6 & 5.7 & 7.3 & 13.8 & 16.5 & Specialty Super \\
3.3 & 4.4 & 5.0 & 5.8 & 3.5 & 4.3 & Convenience \\
7.3 & 6.8 & 6.9 & 7.4 & 6.8 & 5.9 & Other Super \\
46.0 & 45.2 & 45.9 & 42.6 & 40.4 & 43.5 & Specialty \\
24.0 & 24.2 & 22.4 & 22.9 & 21.3 & 16.7 & Semi-specialty \\
0.2 & 0.1 & 0.2 & 0.0 & 0.2 & 0.3 & 0ther \\
\hline
\end{tabular}

a Changes in definitions of specialty super stores, convenience stores, and other super stores in 1997 increases specialty super stores relative to the other two formats and makes the series for the three formats discontinuous. Data using the new definitions are in italics.

Source: Census of Commerce of Japan.

Table 11

Spread of Car Ownership, 1965-98

\begin{tabular}{|c|c|c|}
\hline & $\begin{array}{l}\text { Cars per } \\
1000 \\
\text { persons1 }\end{array}$ & $\begin{array}{l}\text { Change } \\
\% 2\end{array}$ \\
\hline 1965 & 22 & \\
\hline 1970 & 85 & 30.7 \\
\hline 1975 & 154 & 12.7 \\
\hline 1980 & 202 & 5.6 \\
\hline 1985 & 230 & 2.6 \\
\hline 1990 & 291 & 4.8 \\
\hline 1995 & 360 & 4. 4 \\
\hline 1998 & 394 & 3.1 \\
\hline
\end{tabular}

1 Passenger cars per 1000 persons.

2 Average annual perentage change from previous entry.

Source: Japan Statistical Yearbook. 
Table 12

Changes in Japanese Dwellings, 1965-98

\begin{tabular}{|c|c|c|c|c|c|c|}
\hline & $\begin{array}{r}\text { Rooms per } \\
\text { dwelling }\end{array}$ & $\begin{array}{l}\text { Persons per } \\
\text { dwelling }\end{array}$ & room & $\begin{array}{l}\text { Area }\left(\mathrm{m}^{2}\right) \\
\text { dwe1ling }\end{array}$ & $\begin{array}{l}\text { per } \\
\text { person }\end{array}$ & $\begin{array}{l}\text { Change in area } \\
\text { per person }\end{array}$ \\
\hline 1963 & 3.82 & 4.43 & 1.16 & 72.52 & 16.36 & \\
\hline 1968 & 3.84 & 3.96 & 1.03 & 73.86 & 18.63 & 2.6 \\
\hline 1973 & 4. 15 & 3.63 & 0.87 & 77.14 & 21.26 & 2.7 \\
\hline 1978 & 4.52 & 3. 47 & 0.77 & 80.28 & 23.17 & 1.7 \\
\hline 1983 & 4.73 & 3.35 & 0.71 & 85.92 & 25.69 & 2.1 \\
\hline 1988 & 4.86 & 3.21 & 0.66 & 89.29 & 27.86 & 1.6 \\
\hline 1993 & 4.85 & 3.02 & 0.62 & 91.92 & 30.46 & 1.8 \\
\hline 1998 & 4.79 & 2.83 & 0.59 & 92.43 & 32.70 & 1. 4 \\
\hline
\end{tabular}

1 Average annual percentage change between years shown.

Source: Japan Statistical Yearbook. 
Table 13

Measures of Population Density, 1965-95.

\begin{tabular}{ccccc}
\hline \hline & $\begin{array}{c}\text { Dense districts } \\
\text { pop }^{2}\end{array}$ & \multicolumn{2}{c}{ Overall $^{2}$ density } \\
ave $^{4}$ & change $^{5}$ \\
\hline 1965 & 48.1 & 1.23 & 10,263 & - \\
1970 & 53.5 & 1.71 & 8,678 & -3.3 \\
1975 & 57.0 & 2.19 & 7,712 & -2.3 \\
1980 & 59.7 & 2.65 & 6,983 & -2.0 \\
1985 & 60.6 & 2.80 & 6,938 & -0.1 \\
1990 & 63.2 & 3.11 & 6,661 & -0.8 \\
1995 & 64.7 & 3.24 & 6,630 & -0.1 \\
\hline
\end{tabular}

1 Densely inhabited districts are contiguous census districts with high population density (in principle, 4000 inhabitants or more per km2) within the boundary of a city, ward, town, or village constituting an agglomeration of 5000 or more inhabitants.

2 Population of densely inhabited districts as a percentage of Japan's total population.

3 Densely inhabited districts as a percentage of Japan's total area.

4 Overall population denisty per $\mathrm{km} 2$.

5 Annual average percentage change in density since previous census.

Source: Japan Statistical Yearbook. 
Table 14

OLS Log Linear Regressions Explaining the Numbers of Stores of Different Kinds Per Person, with Fixed Effects for Each of Japan(s 47 Prefectures

Dependent variable is number of stores per 1000 people

Coefficient estimates (and t-statistics) for different classes of stores

\begin{tabular}{|c|c|c|c|c|c|c|c|c|}
\hline A11 & Dept & GMS & $\begin{array}{l}\text { Spe- } \\
\text { cialty } \\
\text { Super1 }\end{array}$ & $\begin{array}{l}\text { Conven- } \\
\text { ience }^{1} \\
\end{array}$ & $\begin{array}{l}\text { Other } \\
\text { Super }^{1}\end{array}$ & $\begin{array}{l}\text { Spe }^{-} \\
\text {cialty }\end{array}$ & $\begin{array}{l}\text { Semi- } \\
\text { Spe- }^{-} \\
\text {cialty }\end{array}$ & $\begin{array}{l}\text { Independent variable } \\
\text { names } \\
\text { (except last row) }\end{array}$ \\
\hline $\begin{array}{l}-0.17 \\
(-7.99)\end{array}$ & $\begin{array}{c}0.57 \\
(1.99)\end{array}$ & $\begin{array}{l}0.19 \\
(1.06)\end{array}$ & $\begin{array}{c}0.46 \\
(3.24)\end{array}$ & $\begin{array}{c}0.72 \\
(4.66)\end{array}$ & $\begin{array}{c}0.89 \\
(4.21)\end{array}$ & $\begin{array}{l}-0.23 \\
(-7.07)\end{array}$ & $\begin{array}{l}-0.35 \\
(-8.64)\end{array}$ & $\begin{array}{l}\text { Passenger cars } \\
\text { Per } 1000 \text { persons }\end{array}$ \\
\hline $\begin{array}{l}-0.01 \\
(-0.09)\end{array}$ & $\begin{array}{l}-2.92 \\
(-1.51)\end{array}$ & $\begin{array}{l}3.05 \\
(2.51)\end{array}$ & $\begin{array}{l}-0.15 \\
(-0.15)\end{array}$ & $\begin{array}{l}0.74 \\
(0.65)\end{array}$ & $\begin{array}{l}-0.83 \\
(-0.54)\end{array}$ & $\begin{array}{c}0.45 \\
(2.03)\end{array}$ & $\begin{array}{l}-0.60 \\
(-2.16)\end{array}$ & $\begin{array}{l}\text { Dwelling floor space } \\
\text { Per person }\left(\mathrm{m}^{2}\right)\end{array}$ \\
\hline $\begin{array}{l}-0.37 \\
(-4.12)\end{array}$ & $\begin{array}{l}2.68 \\
(2.22)\end{array}$ & $\begin{array}{l}0.00 \\
(0.00)\end{array}$ & $\begin{array}{l}-0.29 \\
(-0.44)\end{array}$ & $\begin{array}{c}0.73 \\
(1.02)\end{array}$ & $\begin{array}{c}0.32 \\
(0.33)\end{array}$ & $\begin{array}{c}-0.67 \\
(-4.85)\end{array}$ & $\begin{array}{l}-0.62 \\
(-3.58)\end{array}$ & $\begin{array}{l}1000 \text { Persons per } \mathrm{km}^{2} \text { in } \\
\text { dense areas }\end{array}$ \\
\hline $\begin{array}{l}-0.36 \\
(-2.09)\end{array}$ & $\begin{array}{l}0.42 \\
(0.18)\end{array}$ & $\begin{array}{l}-2.21 \\
(-1.52)\end{array}$ & $\begin{array}{l}2.27 \\
(1.74)\end{array}$ & $\begin{array}{l}2.11 \\
(1.47)\end{array}$ & $\begin{array}{l}-2.75 \\
(-1.40)\end{array}$ & $\begin{array}{c}0.25 \\
(0.94)\end{array}$ & $\begin{array}{l}-0.45 \\
(-1.37)\end{array}$ & $\begin{array}{l}\text { Fraction of population } \\
\quad \text { in dense areas } 2\end{array}$ \\
\hline $\begin{array}{c}0.01 \\
(0.88)\end{array}$ & $\begin{array}{l}0.23 \\
(1.48)\end{array}$ & $\begin{array}{l}-0.04 \\
(-0.41)\end{array}$ & $\begin{array}{l}-0.16 \\
(-1.61)\end{array}$ & $\begin{array}{l}0.06 \\
(0.57)\end{array}$ & $\begin{array}{l}-0.21 \\
(-1.39)\end{array}$ & $\begin{array}{l}-0.01 \\
(-0.81)\end{array}$ & $\begin{array}{l}-0.01 \\
(-0.62)\end{array}$ & $\begin{array}{l}\text { Class } 1 \text { Large Stores } \\
\text { Per } 1000 \text { Persons }\end{array}$ \\
\hline $\begin{array}{l}-0.10 \\
(-6.57)\end{array}$ & $\begin{array}{l}-0.18 \\
(-0.85)\end{array}$ & $\begin{array}{c}0.39 \\
(3.01)\end{array}$ & $\begin{array}{c}0.42 \\
(3.37)\end{array}$ & $\begin{array}{l}0.02 \\
(0.17)\end{array}$ & $\begin{array}{l}-0.08 \\
(-0.43)\end{array}$ & $\begin{array}{l}-0.19 \\
(-7.89)\end{array}$ & $\begin{array}{l}-0.11 \\
(-3.84)\end{array}$ & $\begin{array}{l}\text { Class } 2 \text { Large Stores } \\
\text { Per } 1000 \text { Persons }\end{array}$ \\
\hline 0.98 & 0.71 & 0.84 & 0.98 & 0.98 & 0.96 & 0.96 & 0.98 & $\mathrm{R}^{2}$ \\
\hline
\end{tabular}

All variables are in natural logs except the fraction of population residing in densely inhabited districts.

Number of observations (except for specialty super stores and convenience stores) $=235=47$ prefectures X 5 years of observations.

Sample $=5$ successive census of commerce reports 1985, 1988, 1991, 1994, and 1997, by prefecture, except as noted.

Coefficients on prefecture dummies are not reported.

1 No observations for 1997.

2 Densely inhabited districts are contiguous census districts with high population density (in principle, 4000 inhabitants or more per km2) within the boundary of a city, ward, town, or village constituting an agglomeration of 5000 or more inhabitants.

3 Class 1 and class 2 large stores are defined in Table 6. 